\title{
THE STUDY ON IN VITRO DIGESTIBILITY OF SOAKED PALM OIL FIBER BY FILTRATED PALM OIL FRUIT BUNCH ASH
}

\author{
ARI L. DARMAWAN, ASEP IRAWAN, TIDI DHALIKA, ANA R. TARMIDI, MANSYUR, \\ ATUN BUDIMAN, KURNIA A. KAMIL AND IMAN HERNAMAN
}

FACULTY OF ANIMAL HUSBANDRY, UNIVERSITAS PADJADJARAN

Jl. Raya Bandung-Sumedang, Km 21, Jatinangor - Sumedang

e-mail : iman_hernaman@yahoo.com

\begin{abstract}
Palm oil fiber has its potency as feed fiber source for ruminant, but contains high lignin and causes limited digestibility. This research was carried out to find the effect of soaking palm oil fiber in filtrated palm oil fruit bunch ash (FPOFBA) on in vitro digestibility. This experiment used a completely randomized design that repeated for 4times. Palm oil fruit bunch ash was mixed in water and entered into container for 24 hours within concentrations, consists of: 50, 100, 150 and $200 \mathrm{~g} / \mathrm{L}$. Moreover, this filtrate used to soak palm oil fiber for 3 hours. The processed products were analyzed for their level of lignin and crude fiber. Meanwhile, in vitro test was used to measure digestibility. It showed that soaking in filtrated palm oil fruit bunch ash gave significant effect to decrease level of lignin and crude fiber $(\mathrm{P}<0.05)$, and without soaking to improve digestibility of dry and organic matter compared to control treatment $(\mathrm{P}<0.05)$. Treatment with $150 \mathrm{~g} / \mathrm{L}$ and $200 \mathrm{~g} / \mathrm{L}$ using filtrated palm oil fruit bunch ash produced low level of lignin $(\mathrm{P}<0.05$ ), as of: 17.25 and 18.53\%. In contrast, within concentration of $150 \mathrm{~g} / \mathrm{L}$ produced higher level of crude fiber compared to $200 \mathrm{~g} / \mathrm{L}$ (46.04 vs. 43.87\%). This seemed to have the same results in digestibility of dry and organic matter ( $\mathrm{P}>0.05$ ), such as 23.48 and $24.12 \%$ as well as 16.70 and $17.06 \%$ in each. It can be concluded that soaked palm oil fiber with $150 \mathrm{~g} / \mathrm{L}$ concentration of filtrated palm oil fruit bunch ash was more effective in improving digestibility.
\end{abstract}

Keywords: ash, crude fiber, digestibility, lignin, and palm oil

\section{INTRODUCTION}

Processing of palm oil fruit becomes crude palm oil (CPO) will produce palm oil fiber as feed ruminant. According to Jalaludin et al. (1991) in 1 ton of palm oil fruit could produce $180-260 \mathrm{~kg}$ of palm oil fiber. This amount is equal to $5.060 \mathrm{~kg}$ palm oil fiber in each hectare per year. Palm oil fiber contains high fiber but low protein, each consists of: 46.1 and 6.2\% (Mathius, et al. 2003). However, oil palm fiber contains lignin as high as 12.91\%-21.92\% (Irawadi et al. 1996; Suharto, 2004). Lignin bound cellulose and hemicellulose which difficult to be broken until low level of digestibility (Komar, 1984).

An effort to break the bounding of lignocellulose and lignohemicellulose conducted with alkali compound (Komar, 1984). Alkali has its potency to process palm oil fiber which is obtained from ash that dissolved with water. Filtrate of cacao ash could improve organic matter digestibility of corn straw to goat (Adebowale, 1985).

Palm oil fruit bunch ash yields abundant. Currently, it has been exploited for fertilization of palm oil plants. Mineral composition of palm oil fruit bunch ash, consists of: Kalium (K) 25.8\%; Natrium (Na) 0.03\%; Calcium
(Ca) 2.7\%; Magnesium (Mg) 2.8\%; Chlor (Cl) 4.9\%; Carbonate (CO3) 9.2\%; Phosfat (P) 0.2\%; Silica (SiO2) 19.1\% (Zahrina, 2007). It can be analyzed that palm oil fruit bunch ash has high level of alkali. In consequences, it can be used to process palm oil fiber if dissolved in water and expected to improve digestibility.

\section{MATERIALS AND METHODS}

Palm oil fruit bunch ash in each treatments, as of: 5 (T2), 10 ( $\left.\mathrm{T}_{3}\right), 15\left(\mathrm{~T}_{4}\right)$, and $20 \mathrm{~g}\left(\mathrm{~T}_{5}\right)$ poured into container and mixed with $100 \mathrm{~mL}$ of water. Mixture precipitated for 24 hours and filtered with Whatman No. 41 paper and obtained filtrated palm oil fruit bunch ash/FPOFBA (g/L). Then, $100 \mathrm{~g}$ palm oil fiber were mixed with FPOFBA according to its treatment. After that, they were poured into plastic bag and tighten for soaking approximately about 3 hours in room temperature. Hydrolyzed result was dried to test level of crude fiber (AOAC, 1991), lignin (Van Soest, 1967) and in vitro digestibility (Tilley and Terry 1963). The whole treatments were compared to control (palm oil fiber/T1). This experiment was using a completely randomized design and collected data were analyzed with Duncan's test (Steel and Torrie, 1983). 


\section{RESULTS AND DISCUSSION}

The results indicated that processing palm oil fiber with FPOFBA degraded level of lignin (Figure 1). FPOFBA has a high level of alkalinity at $9.73-9.84 \mathrm{pH}$. Basically, alkali works: (1) to break the bounding between cellulose and hemicellulose with lignin and silica, (2) to esterify acetyl group to form uronic acid, and (3) to break cell wall structure by developing of fiber network in which facilitate penetration by microorganism enzyme molecule (Komar, 1984). Processing of dry Sorghum plumosum grass var. Timorense was soaked by filtrate of rice hull ash at concentration of $15 \%$ for 1.5 hours decreased 20.28\% level of lignin (Dato, 1998).

The same result indicated that crude fiber of palm oil fiber was lower than after being soaked with FPOFBA (Figure 2). This condition was caused by the existence of decreasing level of lignin compound. Lignin was crude fiber component and decreasing lignin level caused by degraded level of crude fiber of palm oil fiber. Meanwhile, other crude fiber components such as cellulose and hemicellulose lose due to dissolved in FPOFBA. According to Anggorodi (1984), crude fibers are cellulose and hemicelluloses, insoluble in water but dissolve in watery alkali and break in watery acid. Suwandyastuti et al. (1984) reported that damping of rice straw with $3 \%$ solution $\mathrm{NaOH}$ and using $10 \%$ filtrate of rice hull ash that enriched with $4 \%$ urea, $0.2 \%$ brimstone, $1.8 \%$ salt, and $1 \%$ lime could degrade level of crude fiber of rice straw as high as $1.7 \%$ and $2 \%$.

At Figure 2, indicated that processing with FPOFBA could increase digestibility of dry and organic matter with the highest result obtained in treatment $\mathrm{T}_{3}$ and $\mathrm{T} 4$ (23.48 versus $24.12 \%$ and $16.70 \%$ versus $17.60 \%$ ). Hydrolysis activity by FPOFBA could break its bounding marked by decreasing level of lignin. In consequences, enzymecellulaseand hemicellulaseproduced bybacterial rumen could degrade cellulose and hemicelluloses and improve digestibility. Sutrisno et al. (1986) reported that processing of rice straw using filtrate of rice hull ash could increase digestibility coefficient. Ismadi (1990) conducted a research on bagasse that was splashed with $20 \%$ filtrate of rice hull ash, then covered tightly and soaked for 21 days. It showed that there was a degradation of fiber composition, except silica and improvement of its digestibility compared to control.

Soaked palm oil fiber by $150 \mathrm{~g} / \mathrm{L}$ concentration of filtrated palm oil fruit bunch ash was more effective to increase digestibility.

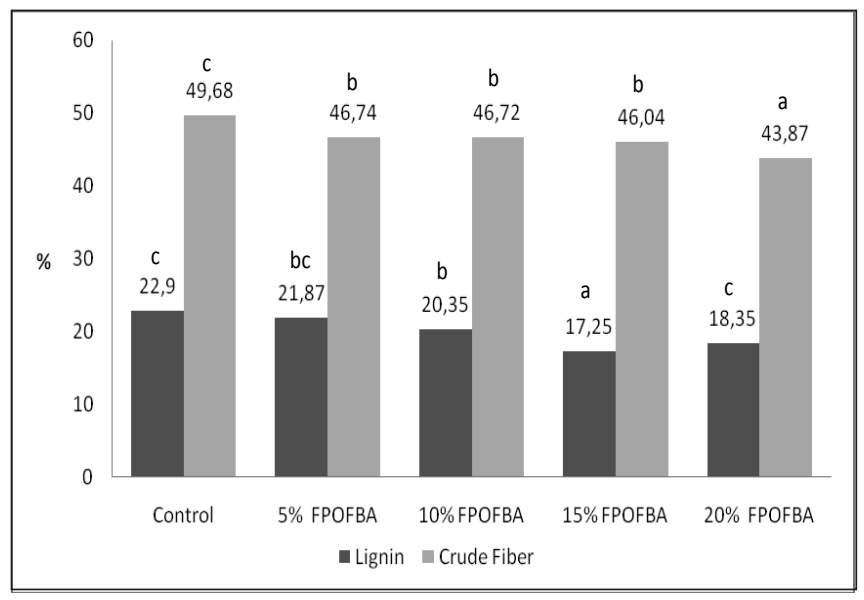

Figure 1. The Effect of Soaked of Palm Oil Fiber by FPOFBA on Lignin and Crude Fiber

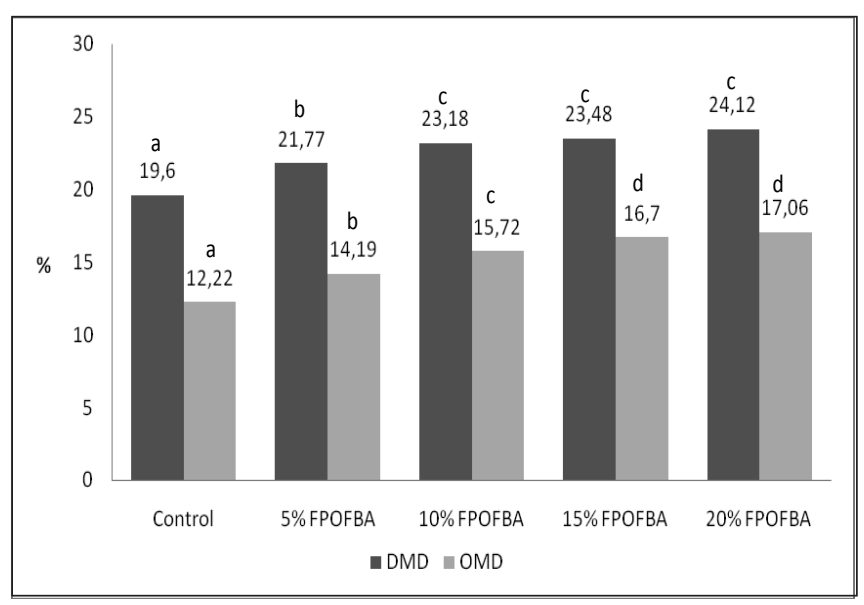

Figure 2. The Effect of Soaked of Palm Oil Fiber by FPOFBA on Dry Matter Digestibility (DMD) and Organic Matter Digestibility (OMD) In Vitro

\section{REFERENCES}

Adebowale, E. A. 1985. Organic Waste Ash as Possible Source of Alkali for Animal Feed Treatment. Animal Feed Science and Technology.

Anggorodi, R. 1994. Ilmu Makanan Ternak Umum. PT Gramedia Utama, Jakarta.

Association of Official Analytical Chemists (AOAC). 1980. Official Methods of Analysis Association of Official Analytical Chemists. $13^{\text {th }}$ Edition.

Dato, T. O. D. 1998. Pengolahan Rumput Sorgum plumosum var. Timorense Kering dengan Filtrat Abu Sekam Padi terhadap Perubahan Komponen Serat dan Kecernaannya secara In Vitro. Tesis. Program Pascasarjana Universitas Padjadjaran, Bandung.

Irawadi, T. T., Sailah, I., Chaniago, T., dan Winugroho. 1996. Pemanfaatan Limbah Serat Pengolahan Kelapa Sawit untuk Produksi Enzim Pemecah Bahan Lignoselulosik dan Produksi Pakan Ternak. Laporan Riset Unggulan Terpadu II. Kerjasama Pusat Antar Universitas Bioteknologi Institut Pertanian Bogor dengan Direktorat Riset Negara dan Puspitek, Bogor. 
Ismadi, V. D. Y. B. 1990. Peningkatan Manfaat Ampas Tebu melalui Pengolahan dengan Larutan Abu Sekam Padi, Urea, dan Sumber Urease sebagai Bahan Pakan yang Diberikan pada Domba. Tesis. Program Pascasarjana Universitas Padjadjaran, Bandung.

Komar, A. 1984. Teknologi Pengolahan Jerami sebagai Makanan Ternak. Yayasan Dian Grahita, Bandung.

Mathius, I W., Sitompul, D., Manurung, B. P., dan Asmi. 2003. Produk Samping Tanaman dan Pengolahan Buah Kelapa Sawit sebagai Bahan Dasar Pakan Komplit untuk Sapi: Suatu Tinjauan. Prosiding. Lokakarya Nasional: Sistem Integrasi Kelapa Sawit-Sapi. Bengkulu 9-10 September 2003.
Steel, R. G. D., dan Torrie, J.H. 1993. Prinsip dan Prosedur Statistika. PT. Gramedia Pustaka Utama.

Sutrisno, C. I., Soelistyono H. S., dan Slamet W., 1986. Potensi Kualitatif dan Kuantitatif Makanan Ternak Ruminansia Besar dalam Kaitannya dengan Efisiensi Usaha Ternak. Dalam: Mukernas III PPSKI, Salatiga.

Tilley, J. M. A. and Terry, R. A. 1963. A Two Stage Technique for In Vitro Digestion of Forage Crops. J. British Grassland Vol 18.

Van Soest, P. J. 1967. Development of a Comprehensive System of Feed Analysis and Its Application to Forages.

Zahrina. I. 2007. Pemanfaatan Abu Sabut dan Cangkang Sawit sebagai Sumber Silika pada Sintesis ZSM-5 dan Zeolit Alam. Jurnal Sains dan Teknologi 6. (2). 